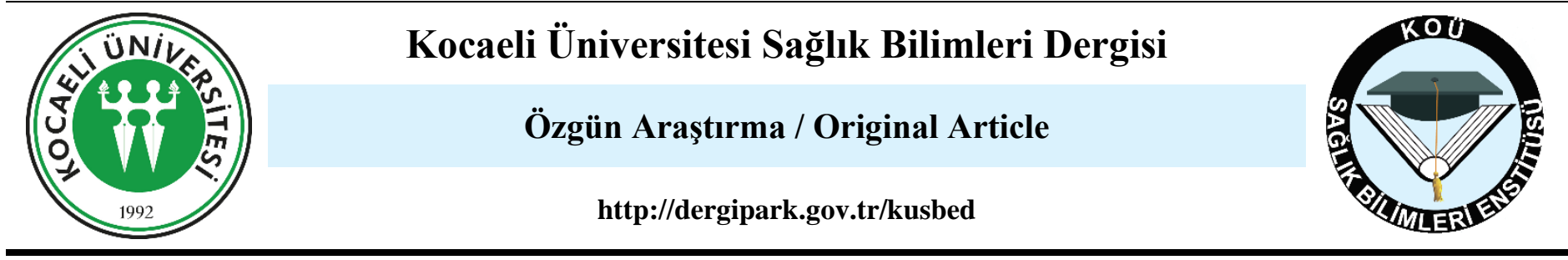

\title{
HEPCIDIN AND VITAMIN D LEVELS: MUTUAL EFFECTS IN ANEMIA OF CHRONIC KIDNEY DISEASE
}

\section{HEPCIDIN VE VITAMIN D: KRONIK BÖBREK HASTALIĞI ANEMISINDDE KARŞILIKLI ETKILEŞIM}

Berna Üstüner ${ }^{1}$ @ (Dibel Gökçay Bek², (D) Necmi Eren², (D) Serkan Bakırdöğen ${ }^{3}$, Betül Kalender Gönüllü²

Kocaeli University, ${ }^{1}$ Internal Medicine, ${ }^{2}$ Nephrology Department, Kocaeli, Turkey, ${ }^{3}$ Çanakkale University 18 Mart Hospital, Internal Medicine, Nephrology Department, Çanakkale, Turkey

ORCID iD: Berna Üstüner: 0000-0003-2222-9431; Sibel Gökçay Bek: 0000-0003-3325-5993; Necmi Eren: 0000-0002-2708-3470; Serkan Bakırdöğen: 0000-0002-3448-0490; Betül Kalender Gönüllü: 0000-0002-3479-8300

\begin{tabular}{lcc}
\hline *Sorumlu Yazar / Corresponding Author: Sibel Gökçay Bek, e-posta / e-mail: beksibel@ gmail.com & \\
\hline Geliş Tarihi / Received: 24.12 .2019 & Kabul Tarihi / Accepted: 18.02 .2021 & Yayım Tarihi / Published: 29.05.2021 \\
\hline
\end{tabular}

\begin{abstract}
Objective: Hepcidin is a peptide with anti-microbial properties that is largely synthesized in the liver and has important roles in iron homeostasis, with serum levels elevated in chronic inflammatory conditions, including chronic kidney disease (CKD). Our aim was to discuss on the role of vitamin D in regulation of hepcidin and anemia of CKD.

Methods: The study group included 103 patients with CKD and 59 healthy individuals. The serum concentration of hepcidin was measured using ELISA, and the association to the following factors was evaluated: age, sex, body mass index, renal functions (estimated glomerular filtration rate, eGFR), drug history, serum biochemistry, complete blood count, iron and total iron binding capacity, ferritin, vitamin D, high sensitive C-reactive protein, C-reactive protein, and the erythrocyte sedimentation rate.

Results: The mean age of the CKD group was $58.63 \pm 11.8$ years (with 16, 26, 27, 19, and 15 patients; respectively in each chronic kidney disease stage, from I through $\mathrm{V}$ and nine on haemodialysis, six on peritoneal dialysis). The mean hepcidin concentration was higher in the chronic kidney disease $(30.3 \pm 24.7 \mathrm{ng} / \mathrm{ml})$ than control $(17.8 \pm 8.4 \mathrm{ng} / \mathrm{ml})$ group $(p<0.05)$. There was a positive association between hepcidin and CRP, ESR and the following serum factors (urea, creatinine, ferritin, phosphate, $\mathrm{pH}$, parathyroid hormone and alkaline phosphatase), with a negative association with eGFR, haemoglobin, haematocrit, calcium, magnesium, 25-OH vitamin D and bicarbonate levels.

Conclusion: Hepcidin levels were found negatively correlated with $25-\mathrm{OH}$ vitamin D levels which was related with the inflammatory effects of vitamin D and hepcidin.
\end{abstract}

Keywords: Anaemia, Chronic kidney disease, Hepcidin,

\section{$\ddot{O} z$}

Amaç: Hepsidin, kronik böbrek hastalığı $(\mathrm{KBH})$ dahil olmak üzere kronik inflamatuar hastalarda serum seviyesi artan büyük oranda karaciğerde sentezlenen bir peptiddir. Amacımız, hepsidin ve KBH anemisinin düzenlenmesinde D vitamininin rolünü tartışmaktır.

Yöntem: Çalışma grubuna $103 \mathrm{KBH}$ 'li hasta ve 59 sağlıklı birey dahil edildi. Hepsidinin serum konsantrasyonu ELISA kullanılarak ölçüldü ve aşağıdaki faktörlerle ilişki değerlendirildi: yaş, cinsiyet, vücut kitle indeksi, böbrek fonksiyonları (tahmini glomerüler filtrasyon hızı, eGFR), ilaç geçmişi, serum biyokimyası, tam kan sayımı, demir ve toplam demir bağlama kapasitesi, ferritin, D vitamini, yüksek duyarlı C-reaktif protein, Creaktif protein ve eritrosit sedimantasyon hizı (ESR).

Bulgular: KBH grubunun ortalama yaşı 58,63 $\pm 11,8$ yıldı ve sırasıyla 16, 26, 27, 19 ve 15 hasta; her bir kronik böbrek hastalı̆̆1 evresinde, I'den V'ye ve dokuz hemodiyalizde, alt1 periton diyalizinde hasta tespit edildi. KBH'da ortalama hepsidin konsantrasyonu ( $30,3 \pm 24.7 \mathrm{ng} / \mathrm{ml})$, kontrol $(17,8 \pm 8,4 \mathrm{ng} / \mathrm{ml})$ grubundan daha yüksek bulundu $(p<0,05)$. Hepsidin ve CRP, ESR, üre, kreatinin, ferritin, fosfat, $\mathrm{pH}$, paratiroid hormonu ve alkalin fosfataz arasında pozitif; eGFR, hemoglobin, hematokrit, kalsiyum, magnezyum, 25 -OH D vitamini ve bikarbonat seviyeleri ile negatif korelasyon gösterilmiştir.

Sonuç: Hepsidin ve D vitamini arasinda, inlamatuar etkilerine baglantili negatif korelasyon gösterilmiştir.

Anahtar Kelimeler: Anemi, Kronik böbrek hastalı̆̆l, Hepsidin, 


\section{Introduction}

The iron-regulatory protein hepcidin is synthesised, predominantly in the liver, as an 84-amino acid prepropeptide (pre-prohepcidin), with lower expression detected by the kidneys, heart, and brain. ${ }^{1}$

Hepcidin is the master regulator of iron homeostasis, with low levels having being identified in patients with an absolute iron deficiency and high levels among patients with anaemia associated with chronic diseases. Anemia in chronic disease is characterized by a hyperferritinemia, with adequate reticuloendothelial iron stores, and affects patients with a wide variety of diseases, including infection, malignancy and inflammatory conditions, such as chronic kidney disease (CKD). ${ }^{2}$ Patients with chronic inflammatory conditions frequently present with disorders of iron metabolism, resulting in alterations in hepcidin levels. Identification of the underlying causes of hepcidin level elevation in CKD, as well as the reversibility of these causes, is very important for the development of effective anti-hepcidin therapies.

Over the last few years, vitamin D deficiency, which is highly prevalent in patientswith CKD, has emerged as a contributory factor to the development of an excess of hepcidin in CKD, with both hepcidin and vitamin D targeted as potential treatment for anaemia in CKD. Vitamin D is known to affect erythropoiesis by promotion of hepcidin synthesis and by a direct effect on erythroid progenitor cells. ${ }^{3,4}$ Anemia was found linked with vitamin D deficiency $^{5,6}$ and after an oral dose of vitamin D2, 34\% decrease in serum hepcidin concentration was reported. ${ }^{7}$ It was suggested that vitamin $\mathrm{D}$ deficiency with elevated hepcidin levels decreased systemic iron resources. To date, although, the efficacy of vitamin D for the treatment of anaemia of CKD remains to be proven. Therefore, our aim in this study was to investigate the determinants of hepcidin in patients with $\mathrm{CKD}$, particularly its relation to vitamin $\mathrm{D}$ in the pathogenesis of anemia.

\section{Methods}

The study group for this cross-sectional and observational study included 103 patients with CKD and 59 healthy volunteers. In formed consent from all participants and approval of local ethics committee were obtained before the study. The exclusion criteria were as follows: presence of an acute infection; chronic inflammatory disease; history of malignancy; pregnancy; age $<18$ years and $>80$ years; parenteral iron replacement or blood transfusion with in six months prior to enrolment; history of bleeding within four weeks prior to enrolment; history of bleeding disorder; erythropoietin (EPO) treatment within two months prior to enrolment; history of liver disease or hepatitis $\mathrm{B}$ or $\mathrm{C}$ infection; corticosteroid treatment; history of hemochromatosis or thalassemia; and history of hyperparathyroidism.

The following demographic characteristics were recorded: anthropometric measures of height and weight; body mass index (BMI); history of smoking and medical treatment; modality of renal replacement treatment; and comorbid diseases. Blood samples were obtained after at least eight hour of fasting and before the peritoneal or haemodialysis session. Three millimetres of blood samples were used for hepcidin measurement; these samples were centrifuged at $3000 \mathrm{rpm}$ for $10 \mathrm{~min}$ and frozen at $-20^{\circ} \mathrm{C}$ until analysed.Using the rest of the blood samples, the following serum measurements were obtained: complete blood count; plasma albumin; blood urea nitrogen (BUN); creatinine; Creactive protein (CRP); high sensitive CRP; alkaline phosphatase (ALP); sodium $(\mathrm{Na})$; potassium $(\mathrm{K})$; calcium $(\mathrm{Ca})$; phosphate $(\mathrm{P})$; parathyroidhormone $(\mathrm{PTH}) ; 25-\mathrm{OH}$ vitamin $\mathrm{D}$; ferritin; iron; serum ironbinding capacity (SIBC); thyroid hormones; creatinine clearance; and proteinuria in 24-hour urine samples. Plasma hepcidin-25 levels were measured using enzyme immunoassay (EIA) method (Competition ELISA; DRG International Inc, USA). Results were interpreted in $\mathrm{pg} / \mathrm{ml}$.

\section{Statistical Analysis}

Statistical analysis was performed using SPSS for Windows (version 17.0, Chicago, USA). The distribution of the data set was evaluated prior to analyses. The association between hepcidin level and measured variables was evaluated using Spearman's ro (rho) correlation. Normally distributed categorical variables were described using counts and percentages, with the mean value ( \pm standard deviation) used to describe continuous variables. Non-normally distributed variables were described by the median and range (minimum-maximum). Between-group differences (CKD versus control group) were evaluated usingthe MannWhitney U Test for non-parametric variables and Student's t-test for parametric variables. Comparisons of dependent variables between the two groups were evaluated using a Wilcoxon test. For all analyses, significance was set at $p<0.05$.

\section{Results}

Our study group included 103 patients with CKD (46 women and 57 men, $58.63 \pm 11.8$ years of age) and a control group of 59 healthy individuals (29 women and 30 men, $49.0 \pm 10.5$ years of age). The demographic and biochemical characteristics of the study group are summarised in Table 1. Among the 103 individuals in the CKD group, $59.2 \%$ had diabetes mellitus (DM); $87.4 \%$ hypertension; $23.3 \%$ coronary heart disease (CHD); $12.6 \%$ congestive heart failure (CHF); $4.9 \%$ cerebrovascular disease (CVD); $2.9 \%$ pulmonary artery hypertension (PAH); $8.7 \%$ hypothyroidism; and $3.9 \%$ nephrolithiasis.

With regard to medication use, $61.2 \%$ of individuals in the CKD group were using angiotensin receptor blockers (ARBs); 25.2\% angiotensin converting enzyme inhibitors (ACEinh); $25.2 \%$ calcium (Ca) channel blockers; $6.8 \%$ amino-acids; $13.6 \%$ alfa blockers; $28.2 \%$ diuretics; $40.8 \%$ beta-blockers; $33 \%$ statins; $10.7 \%$ phosphate binders; $7.8 \%$ active vitamin D; $29.1 \%$ insulin; $20.4 \%$ oral antidiabetics; $30.1 \%$ acetyl salicylic acid; and $24.3 \%$ proton pump inhibitors.

Iron-related variables measured were summarised in Table 2. There was a significant difference between-group for hepcidin level, eGFR, ferritin, saturation of transferrin, and the serum level of iron. Levels of inflammatory markers were significantly higher in the CKD and control group, as follows: CRP ( $p=0.008)$; highsensitive CRP ( $p=0.001)$; and sedimentation $(p=0.0001)$.

Hepcidin levels for the different stages of CKD were reported in Table 3, and the correlation between hepcidin and laboratory-based variables in the CKD group was reported in Table 4. Hepcidin level was negatively correlated to the eGFR, and $\mathrm{Hb}$, and positively correlated to ferritin, with no correlation to iron and transferrin saturation. In addition, there was a significant association between 
hepcidin and treatment of bicarbonate, essential amino acids, phosphate binders, allopurinol, and active vitamin D, as well as the use of oral antidiabetics, but not with the use of statins, ACEinh, ARB, Ca channel blockers, alfa blockers, diuretics, beta blockers, and vitamin D. The correlation between hepcidin level and independent variables was summarized in Table 4.

Table 1. Demographic and biochemical characteristics of the study group Patients (n=103) Control $(\mathrm{n}=59) \quad p$

\begin{tabular}{|c|c|c|c|}
\hline Age, years & $58.6 \pm 11.8$ & $49.0 \pm 10.5$ & 0.0001 \\
\hline Male, n (\%) & $57(55.3)$ & $30(50.8)$ & \\
\hline Female, $\mathrm{n}(\%)$ & $46(44.7)$ & $29(49.2)$ & \\
\hline BMI, $\mathrm{kg} / \mathrm{m}^{2}$ & $28.3 \pm 5.5$ & $27.0 \pm 4.4$ & 0.302 \\
\hline Creatinine, $\mathrm{mg} / \mathrm{dL}$ & $2.1 \pm 2.1$ & $0.7 \pm 0.1$ & 0.0001 \\
\hline Urea, $\mathbf{m g} / \mathbf{d L}$ & $74.8 \pm 56.5$ & $29.9 \pm 6.6$ & 0.0001 \\
\hline Creatinine clearance, $\mathrm{ml} / \mathrm{min}$ & $52.1 \pm 38.4$ & - & \\
\hline PTH, pg/mL & $61.7(8.8-850)$ & $42.4(20.8-95.3)$ & 0.0001 \\
\hline Vitamin D $25 \mathrm{OH}, \mathrm{ng} / \mathrm{mL}$ & $18.7 \pm 11.8$ & $17.0 \pm 6.9$ & 0.671 \\
\hline Albumin, $\mathrm{mg} / \mathrm{dL}$ & $4.0 \pm 0.4$ & $4.4 \pm 0.2$ & 0.001 \\
\hline Calcium, mg/dL & $9.1 \pm 0.6$ & $8.8 \pm 0.3$ & 0.0001 \\
\hline Phosphate, mg/dL & $3.7 \pm 1.2$ & $3.1 \pm 0.5$ & 0.001 \\
\hline Magnesium, mg/dL & $2.2 \pm 0.2$ & $2.3 \pm 0.3$ & 0.262 \\
\hline ALP, U/L & $86.3 \pm 28.9$ & $84.2 \pm 28.9$ & 0.469 \\
\hline eGFR, ml/min & $44 \pm 30.5$ & $100 \pm 15.3$ & 0.0001 \\
\hline Uric acid, $\mathbf{m g} / \mathbf{d L}$ & $6.3 \pm 1.9$ & $4.6 \pm 1.1$ & 0.0001 \\
\hline CRP $m g / d L$ & $0.40(0.03-9.72)$ & $0.24(0.02-40.3)$ & 0.008 \\
\hline High sensitive CRP mg/dl & $0.39(0.03-7.12)$ & $0.22(0.01-84.1)$ & 0.001 \\
\hline
\end{tabular}

p-value determined by the Mann-Whitney U test; ALP, alkaline phosphatase

Table 2. Between-group comparisons in iron-related variables

\begin{tabular}{llll}
\hline & $\begin{array}{l}\text { Patients } \\
(\mathbf{n}=\mathbf{1 0 3})\end{array}$ & $\begin{array}{l}\text { Control } \\
\text { group }(\mathbf{n = 5 9})\end{array}$ & $\boldsymbol{p}$ \\
\hline Hepcidin, ng/ml & $30.3 \pm 24.7$ & $17.8 \pm 8.4$ & $\mathbf{0 . 0 1 6}$ \\
eGFR, ml/min & $44 \pm 30.5$ & $100 \pm 15.3$ & $\mathbf{0 . 0 0 0 1}$ \\
Haemoglobin, g/dL & $12.6 \pm 1.8$ & $14.2 \pm 1.3$ & $\mathbf{0 . 0 1}$ \\
Haematocrit, \% & $38.3 \pm 5.6$ & $43.2 \pm 3.7$ & $\mathbf{0 . 0 0 2}$ \\
MCV, fL & $90.3 \pm 5.4$ & $91.4 \pm 4.6$ & 0.368 \\
MPV, fL & $7.9 \pm 1$ & $7.7 \pm 1.1$ & 0.545 \\
Serum ferritin, ng/mL & $90.6 \pm 149.7$ & $47.4 \pm 44.1$ & $\mathbf{0 . 0 4 1}$ \\
Serum iron, $\boldsymbol{\mu g} / \mathbf{d L}$ & $61.7 \pm 25.7$ & $82.5 \pm 30.8$ & $\mathbf{0 . 0 0 0 1}$ \\
Serum transferrin & & & \\
saturation, \% & $\% 21.7 \pm 9.0$ & $27.6 \pm 11.0$ & $\mathbf{0 . 0 0 1}$ \\
\hline
\end{tabular}

eGFR, estimated glomerular filtration rate; $\mathrm{MCV}$, mean corpuscle volume; MPV, mean platelet volume.
Table 3. Hepcidin levels for the different stages of CKD Hepcidin (ng/ml)

$\begin{array}{ll}\text { Stage I } & 26.9 \pm 23.6 \\ \text { Stage II } & 12.1 \pm 8.1 \\ \text { Stage III } & 21.1 \pm 17.3 \\ \text { Stage IV } & 40.4 \pm 27.0 \\ \text { Stage V } & 52.8 \pm 23.9\end{array}$

CKD: chronic kidney disease

Table 4. Correlation between hepcidin level and laboratory-based variables in the CKD group

\begin{tabular}{lll}
\hline Correlation of hepcidin & $\mathbf{r}$ & $\boldsymbol{p}$ \\
Glucose & -0.051 & 0.611 \\
Creatinine & 0.529 & $\mathbf{0 . 0 0 0 1}$ \\
BUN & 0.615 & $\mathbf{0 . 0 0 0 1}$ \\
Urea & 0.617 & $\mathbf{0 . 0 0 0 1}$ \\
eGFR & -0.522 & $\mathbf{0 . 0 0 0 1}$ \\
Hb & -0.431 & $\mathbf{0 . 0 0 0 1}$ \\
Sedimentation & 0.374 & $\mathbf{0 . 0 0 0 1}$ \\
sCRP & 0.397 & $\mathbf{0 . 0 0 0 1}$ \\
CRP & 0.343 & $\mathbf{0 . 0 0 0 1}$ \\
Ferritin & 0.737 & $\mathbf{0 . 0 0 0 1}$ \\
Iron & -0.177 & $\mathbf{0 . 0 2 4}$ \\
Transferrin Saturation & 0.155 & 0.119 \\
Venous blood Ph & -0.241 & $\mathbf{0 . 0 1 4}$ \\
Venous blood bicarbonate & -0.437 & $\mathbf{0 . 0 0 0 1}$ \\
Venous blood lactate & -0.167 & 0.094 \\
TSH & 0.930 & $\mathbf{0 . 0 0 9}$ \\
PTH & 0.436 & $\mathbf{0 . 0 0 0 1}$ \\
25-OH vitamin D ng/mL & -0.374 & $\mathbf{0 . 0 0 0 1}$ \\
ALP & 0.320 & $\mathbf{0 . 0 0 1}$ \\
Serum albumin & -0.396 & $\mathbf{0 . 0 0 0 1}$ \\
Calcium & -0.428 & $\mathbf{0 . 0 0 0 1}$ \\
Phosphate & 0.454 & $\mathbf{0 . 0 0 0 1}$ \\
(n) & 0.782 & $\mathbf{0 . 0 2 8}$
\end{tabular}

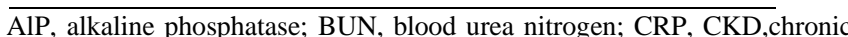
kidney disease; $\mathrm{Hb}$, haemoglobin; MCV, mean corpuscular volume; eGFR, estimated glomerular filtration rate ; PTH, parathyroid hormone; sCRP, sensitive $\mathrm{C}$-reactive protein; and TSH, thyroid-stimulating hormone

\section{Discussion}

Our finding of a higher hepcidin level in the CKD than control group $(p=0.016)$ is consistent with previous studies that have reported a proportional increase in hepcidin with decreasing renal function ${ }^{3,4}$ as well as an increase in hepcidin, as an acute phase protein, in chronic inflammation or infection. ${ }^{8,9}$ This is consistent with our finding of higher levels of hepcidin in the CKD group, compared to the 
control group, with a higher level of hepcidin associated with higher levels of inflammatory markers in the CKD than control group (CRP, $p=0.008$; $\mathrm{SCRP}, p=0.0001$; and ESR, $p=0.0001)$. Of note is the finding by Hamada et al. of a noncorrelation between hepcidin and inflammatory markers (CRP and IL-6) in patients with CKD (predialysis or on haemodialysis) ${ }^{10}$ and it was shown that pro-hepcidin levels in HD patinets were higher than in PD patients. ${ }^{11}$

In our study, hepcidin correlated positively with phosphate and PTH, and negatively with $25-\mathrm{OH}$ vitamin $\mathrm{D}$, a finding that agreed with previous studies that have reported an increase in hepcidin in patients with CKD having vitamin D deficiency. A cell-line study showed that vitamin D directly inhibits hepcidin transcription in hepatocytes through a direct suppression of the transcription of the hepcidin gene, leading to decreased hepcidin synthesis. ${ }^{12}$ Moreover, in hepatocyte and monocyte cell cultures, $25-\mathrm{OH}$ vitamin $\mathrm{D}$ or 1,25 hydroxy vitamin D replacement produced a 0.5 -fold decrease in total hepcidin expression. ${ }^{13}$ Taken together, these findings point towards a potential role of vitamin D in the treatment of anaemia in CKD, resulting from an underlying iron deficiency. Although the efficacy of vitamin D supplementation for the treatment of anaemia in CKD remains to be proven, it could potentially emerge as an ideal therapeutic agent to decrease hepcidin synthesis, and would be safer and more cost effective than the ESAs, iron infusions and blood transfusions. Well-designed future physiological and interventional studies are needed to study the effect of vitamin D replacement on hepcidin levels, iron absorption, iron bio-availability, and haemoglobin levels in CKD. This issue is important to consider based on the findings of a pilot study in healthy human individuals that reported a $34 \%$ decrease in hepcidin levels within 24 hour after administration of a single, oral, large (100 000 IU) dose of $25-\mathrm{OH}$ vitamin D. ${ }^{14}$ Overall, low $25-\mathrm{OH}$ vitamin D levels has been associated with poor iron status. ${ }^{15-17}$ Thus, vitamin D supplementation should be considered as an adjunct in the treatment of anaemia in patients with low vitamin D levels, with or without CKD, or other chronic inflammatory diseases. ${ }^{18}$ In our study, lower levels of 25$\mathrm{OH}$ vitamin $\mathrm{D}$ were associated with a lower level of $\mathrm{Hb}$ and higher hepcidin levels. Therefore, vitamin D deficiency increases the risk of anaemia, lower mean haemoglobin level and higher use of ESAs. among patients with CKD. ${ }^{15}$

The Third National Health and Nutrition Examination Survey reported a vitamin D deficiency of $33.3 \%$ among the non-anemic population, with the prevalence rate rising to $56 \%$ among elderly patients with anaemia associated with chronic inflammation. ${ }^{19}$ Similarly, in their follow-up study of 554 individuals over a two-year period, Sim et al. reported an association between a vitamin D deficiency and a greater risk of anaemia, lower mean haemoglobin level and higher use of ESAs. These findings indicate that 1,25 $\mathrm{OH}$ vitamin D hormone plays a role in the proliferation and maturation of erythroid progenitor cells.Before Sim et al.'s study, ${ }^{15}$ the association between vitamin $\mathrm{D}$ deficiency and ESA use had been reported only among patients with endstage renal disease. According to results of our study, this association was also confirmed in predialysis CKD patients. With regard to therapy, Saab et al. reported a lowering in the dose of epoetin alfa in patients on haemodialysis after ergocalciferol therapy, but anaemia was not a primary outcome of this study. ${ }^{20}$ Similarly, Aucella et al. demonstrated an increase in erythroid proliferation after administration of 1,25-hydroxyvitamin D among patients with end-stage renal disease, which was synergistic with epoetin alfa. $^{21}$

In vitro studies demonstrated that $1,25 \mathrm{OH}$ vitamin $\mathrm{D}$ enhanced the stimulatory effect of EPO on the growth of erythroid precursor cells ${ }^{4}$; however, further research is needed to define the efficacy of vitamin $\mathrm{D}$ as treatment of anaemia. In our study, we identified a positive correlation between hepcidin level and replacement of active $D$ vitamin ( $p=0.001, \mathrm{r}=0.311)$ in the CKD group. It is likely that an active vitamin D may increases renal absorption of calcium and phosphate from the kidneys, resulting in increase in extracellular calcium level and, thus, a decrease in hepcidin level. However, we cannot confirm this pathway from our results as only five patients in the CKD group had been treated with vitamin D supplementation, with no difference in hepcidin level among these patients and the rest of the CKD group ( $p=0.033)$. However, we did identify a negative correlation between hepcidin and $25-\mathrm{OH}$ vitamin $\mathrm{D}$ in the CKD group ( $p=0.0001, \mathrm{r}=-0.374)$, which might reflect the anti-inflammatory effects of vitamin $\mathrm{D}$ described in recent studies. ${ }^{18}$

An increase in hepatic iron levels with magnesium deficiency has previously been reported in rats ${ }^{22}$, which was associated with an increase in hepcidin expression by BMP6, due to the oxidative stress caused by the magnesium deficiency. This is the only study we identified in the literature to have reported on the relationship between magnesium and hepcidin. However, in our CKD group, we did identify an increase in hepcidin among patients with a low level of magnesium $(p<0.001)$.

Our finding of an increase in hepcidin level with increasing stage of CKD has previously been reported ${ }^{23}$.As chronic renal disease progressed, ferritin increased, while $\mathrm{Hb}$, iron, and transferrin saturation decreased. We further identified a significant association between hepcidin level and various treatments: bicarbonate replacement $(p<0.001)$; essential amino acid $(p<0.05)$; phosphate binders $(p<0.05)$; allopurinol $(p<0.001)$; and oral antidiabetic treatment $(p<0.05)$. Although the relationship between hepcidin and these treatments has not previously been reported, we postulate that identified effects were related to the advancing stage of CKD rather than to the treatment itself.

The progression of CKD is associated with metabolic acidosis, resulting in a decrease in bicarbonate level and increase in hepcidin. Of note, in our study, although we did identify a negative correlation between hepcidin level and venous blood gas $\mathrm{pH}(\mathrm{r}=-0.241, p<0.05)$, bicarbonate $(\mathrm{r}=-$ $0.437, p<0.001)$, the difference in bicarbonate for the different levels of hepcidin was not significant $(p>0.659)$, despite significant differences for other venous blood gas parameters: $\mathrm{pH}(p<0.001)$; lactate $(p<0.001)$; $\mathrm{PO}_{2}(p<0.05)$; and $\mathrm{PCO} 2(p<0.001)$. Of note, we did not identify a correlation between hepcidin and lactate levels ( $\mathrm{r}=-0.167$, $p=0.094)$. Maisetta et $\mathrm{al}^{24}$ reported an increase in bactericidal activity with increased levels of hepcidin and, therefore, hepcidin could provide effective control by increasing acidosis. However, the relationship between hepcidin and lactate and bicarbonate has not been previously reported. There are many factors such as vitamin D, PTH level, calcium and phosphate concentration, metabolic acidosis and magnesium levels, which are well known factors to contribute to bone metabolism and function. In addition to hepcidin, these factors are important determinants of anemia in CKD. ${ }^{25}$

In conclusion, our study provides the evidence of an association between hepcidin level and iron status, 
microinflammation and metabolic acidosis, as well as vitamin D and magnesium levels. Therefore, hepcidin might be a promissing biomarker and diagnostic test for iron status in CKD, although for the association between hepcidin with vitamin D and magnesium; future research is still needed to confirm our findings.

\section{Author Contributions}

BU, SB, NE, SB, BKG: Design; BU, SB, BKG: Project development; BU, SB, SB: Analysis; BU, SB, NE: Literature search; SB, BU, NE, SB: Manuscript writing; SB, NE, BK: Critical review

\section{References}

1. Pigeon C, Ilyin G, Courselaud B et al. A newmouseliverspecific gene, encoding a protein homologous to human antimicrobial peptide hepcidin, is overexpressed during iron overload. $J$ BiolChem 2001;276: 7811 - 7819 . doi:10.1074/jbc.m008923200

2. Means RT. Hepcidin and Cytokines in Anaemia. Hematology, 2004; 9, 357-362. doi:10.1080/10245330400018540

3. Smith, E.M.; Alvarez, J.A.; Kearns, M.D.; Hao, L.; Sloan, J.H.; Konrad, R.J.; Ziegler, T.R.; Zughaier, S.M.; Tangpricha, V. High-dose vitamin D3 reduces circulating hepcidin concentrations: A pilot, randomized, double-blind, placebocontrolled trial in healthy adults. Clin. Nutr. 2017, 36, 980985 doi:10.1016/j.clnu.2016.06.015

4. Alon, D.B.; Chaimovitz, C.; Dvilansky, A.; Lugassy, G.; Douvdevani, A.; Shany, S.; Nathan, I. Novel role of $1,25(\mathrm{OH})(2) \mathrm{D}(3)$ in induction of erythroid progenitor cell proliferation. Exp. Hematol. doi: 10.1016/s0301472x(02)00789-0.

5. Thomas, C.E.; Guillet, R.; Queenan, R.A.; Cooper, E.M.; Kent, T.R.; Pressman, E.K.; Vermeylen, F.M.; Roberson, M.S.; O'Brien, K.O. Vitamin D status is inversely associated with anemia and serum erythropoietin during pregnancy. Am. J. Clin. Nutr. 2015, 102, 1088-1095. doi: 10.3945/ajen.115.116756.

6. Nikooyeh, B.; Neyestani, T.R. Poor vitamin D status increases the risk of anemia in school children: National Food and Nutrition Surveillance. Nutrition 2018, 47, 69-74. doi: 10.1016/j.nut.2017.09.008.

7. Bacchetta, J.; Zaritsky, J.J.; Sea, J.L.; Chun, R.F.; Lisse, T.S.; Zavala, K.; Nayak, A.; Wesseling-Perry, K.; Westerman, M.; Hollis, B.W.; et al. Suppression of iron-regulatory hepcidin by vitamin D. J. Am. Soc. Nephrol. 2014, 25, 564-572. doi: 10.1681/ASN.2013040355

8. Ashby DR, Gale DP, Busbridge M, Murphy KG, Duncan ND, et al. Plasma hepcidin levels are elevated but responsive to erythropoietin therapy in renal disease. Kidney Int 2009; 75 : 976-81. doi: 10.1038/ki.2009.21.

9. Maruyama Y, Yokoyama K, Yamamoto H, Nakayama M, Hosoya T. Do serum hepcidin-25 levels correlate with oxidative stress in patients with chronic kidney disease not receiving dialysis? Clin Nephrol. 2012;78:281-286. doi: $10.5414 / \mathrm{CN} 107424$

10. Hamada $\mathrm{Y}$, Kono TN, Moriguchi $\mathrm{Y}$ et al. Alteration of mRNA expression of molecules related to iron metabolism in adenine-induced renal failure rats: a possible mechanism of iron deficiency in chronic kidney disease patients on treatment .Nephrol Dial Transplant2008;23: 1886 - 1891. doi: 10.1093/ndt/gfm900

11. Turgut, F., Kanbay, M., Altay, M., Uz, E., Bavbek, N. et al. Pro-Hepcidin Levels in Peritoneal Dialysis and Hemodialysis Patients. Dial. Transplant. 2009, 38: 203-209. https://doi.org/10.1002/dat.20297

12. Bacchetta J, Zaritsky JJ, Sea JL, Chun RF, Lisse TS, Zavala $\mathrm{K}$, et al. Suppression of Iron-Regulatory Hepcidin by Vitamin D.J AmSocNephrol. 2014; 25: 564-572. doi: 10.1681/ASN.2013040355
13. Zughaier SM, Alvarez JA, Sloan JH, Konrad RJ, Tangpricha $\mathrm{V}$. The role of vitamin $\mathrm{D}$ in regulating the iron-hepcidinferroportin axis in monocytes. J ClinTranslEndocrinol. 2014; 1: 19-25. doi: 10.1016/j.jcte.2014.01.003

14. Madar AA, Stene LC, Meyer HE, Brekke M, Knutsen KV. Effect of vitamin D3 supplementation on iron status: a randomized, double-blind, placebo-controlled trial among ethnic minorities living in Norway.Nutr J. 2016;15-74. doi: 10.1186/s12937-016-0192-7

15. Sim JJ, Lac PT, Liu IL, Meguerditchian SO, Kumar VA, Kujubu DA et al. Vitamin D deficiency and anemia: a crosssectional study. AnnHematol. 2010; 89:447-452. doi: 10.1007/s00277-009-0850-3

16. McGillivray G, Skull SA, Davie G, Kofoed SE, Frydenberg A, Rice $J$ et al. High prevalence of asymptomatic vitamin D and iron deficiency in East African immigrant children and adolescents living in a temperate climate. ArchDis Child. 2007; 92:1088-1093. doi: 10.1136/adc.2006.112813

17. Blanco-Rojo R, Perez-Granados AM, Toxqui L, Zazo P, de la Piedra C, Vaquero MP. Relationship between vitamin D deficiency, bone remodelling and iron status in iron-deficient young women consuming an iron-fortified food. Eur J Nutr. 2013; 52:695-703. doi: 10.1007/s00394-012-0375-8

18. Donate-Correa J, Dominguez-Pimentel V, Mendez-Perez ML, Muros-de-Fuentes M, Mora-Fernandez C, Martin-Nunez E, et al. Selective vitamin $\mathrm{D}$ receptor activation as antiinflammatory target in chronic kidney disease. Mediators of Inflammation, 2014;670475. doi: 10.1155/2014/670475

19. Todd S. Perlstein, ReenaPande, Nancy Berliner and Gary J. Vanasse. Prevalence of 25-hydroxyvitamin D deficiency in subgroups of elderly persons with anemia: association with anemia of inflammation. Blood 2011; 117: 2800-2806. doi: 10.1182/blood-2010-09-309708

20. Saab G, Young DO, Gincherman Y, Giles K, Norwood K, Coyne DW. Prevalence of vitamin D deficiency and the safety and effectiveness of monthly ergocalciferol in hemodialysis patients. NephronClinPract 2007; 105:132-138. doi: 10.1159/000098645

21. Aucella F, Scalzulli RP, Gatta G, Vigilante M, Carella AM, Stallone C (2003) Calcitriol increases burst-forming uniterythroid proliferation in chronic renal failure, a synergistic effect with r- HuEpo. NephronClinPract 2003; 95:121-127. doi: 10.1159/000074837.

22. Ishizaki N, Kotani M, Funaba M, Matsui T. Hepcidin expression in the liver of rats fed a magnesium-deficient diet. Brit J Nut. 2011;106:1169-1172. doi: $10.1017 /$ S0007114511001553

23. Uehata T, Tomosugi N, Shoji T, Sakaguchi Y, Suzuki A, Kaneko T, et al. Serum hepcidin-25 levels and anemia in nondialysis chronic kidney disease patients: a cross-sectional study. Nephrology, dialysis, transplantation : official publication of the European Dialysis and Transplant Association - European Renal Association. 2012 ;27:10761083. doi: $10.1093 / \mathrm{ndt} / \mathrm{gfr} 431$

24. Maisetta G, Petruzzelli R, Brancatisano FL, Esin S, Vitali A, Campa M, et al. Antimicrobial activity of human hepcidin 20 and 25 against clinically relevant bacterial strains: effect of copper and acidic pH. Peptides 2010;31:1995-2002. doi: 10.1016/j.peptides.2010.08.007

25. Cunningham J, Rodri'guez M, Messa P. Magnesium in chronic kidney disease Stages 3 and 4 and in dialysis patients. ClinKidney J 2012; 5: 39-51. doi: 10.1093/ndtplus/sfr166 